\title{
About the editors
}

Sabri Boubaker is Professor of Finance at South Champagne Business School (Troyes, France) and Research Fellow at the Institut de Recherche en Gestion (University of Paris Est). He holds a $\mathrm{PhD}$ in Finance from University of Paris Est (2006) and a HDR degree (Habilitation for Supervising Doctoral Research) in 2010 from the same university. He has recently published several academic papers in international refereed journals including Journal of Corporate Finance, Journal of Banking \& Finance, Journal of International Money and Finance, Financial Management, International Review of Financial Analysis, European Financial Management Journal, Review of Quantitative Accounting and Finance and Journal of International Financial Markets, Institutions and Money. Dr Boubaker has also edited several books on corporate finance and financial markets and serves on the editorial boards of several peer-reviewed finance journals. He is the co-founder (with Duc Khuong Nguyen) of the Paris Financial Management Conference and Vietnam Symposium in Banking and Finance (VSBF).

Douglas Cumming is DeSantis Distinguished Professor of Finance and Entrepreneurship at the College of Business, Florida Atlantic University, USA. He holds a JD/PhD in Economics, Finance and Law from the University of Toronto. He has published over 130 academic papers in international refereed journals including Journal of Financial Economics, Review of Financial Studies, Journal of Corporate Finance, Journal of Banking \& Finance, International Review of Financial Analysis, Economic Journal, Journal of Empirical Legal Studies, Academy of Management Journal and Journal of International Business Studies. Dr Cumming has co-authored books on venture capital and hedge funds with Elsevier Science Academic Press and Oxford University Press. Also, Dr Cumming has edited over a dozen books on entrepreneurial finance, private equity and related topics with Oxford University Press, Wiley, Palgrave, and Springer. Dr Cumming is a co-editor at Finance Research Letters and Entrepreneurship Theory and Practice, the founding editor of Annals of Corporate Governance, and serves on the editorial boards of numerous academic journals.

Duc Khuong Nguyen is Professor of Finance and Deputy Director for Research at IPAG Business School (France). He holds a PhD in Finance 
from the University of Grenoble II (France) and a HDR (Habilitation for Supervising Scientific Research) degree in Management Science from University of Cergy-Pontoise (France), and completed an executive education programme in 'Leadership in Development' at Harvard Kennedy School (United States). He is also a Non-Resident Research Fellow at the School of Public and Environmental Affairs, Indiana University, and a Research Associate at the Department of Finance, Centre d'Economie de la Sorbonne, University Paris 1 Panthéon-Sorbonne. His research articles are published in various refereed journals such as Journal of Banking \& Finance, Journal of International Money and Finance, Journal of International Financial Markets, Institutions and Money, Quarterly Review of Economics and Finance and Review of International Economics. Dr Nguyen has edited several books on corporate finance and financial markets issues and serves as subject and associate editor of several finance journals. He is the co-founder (with Sabri Boubaker) of the Paris Financial Management Conference and Vietnam Symposium in Banking and Finance (VSBF). 